\title{
Dietary Cholesterol and the Lack of Evidence in Cardiovascular Disease
}

\author{
Ghada A. Soliman (10) \\ Department of Environmental, Occupational, and Geospatial Health Sciences, CUNY Graduate School of Public \\ Health and Health Policy, The City University of New York, 55 W. 125th Street, New York, NY 10027, USA; \\ ghada.soliman@sph.cuny.edu; Tel.: +1-646-364-9515
}

Received: 18 May 2018; Accepted: 13 June 2018; Published: 16 June 2018

\begin{abstract}
Cardiovascular disease (CVD) is the leading cause of death in the United States. For years, dietary cholesterol was implicated in increasing blood cholesterol levels leading to the elevated risk of CVD. To date, extensive research did not show evidence to support a role of dietary cholesterol in the development of CVD. As a result, the 2015-2020 Dietary Guidelines for Americans removed the recommendations of restricting dietary cholesterol to $300 \mathrm{mg} /$ day. This review summarizes the current literature regarding dietary cholesterol intake and CVD. It is worth noting that most foods that are rich in cholesterol are also high in saturated fatty acids and thus may increase the risk of CVD due to the saturated fatty acid content. The exceptions are eggs and shrimp. Considering that eggs are affordable and nutrient-dense food items, containing high-quality protein with minimal saturated fatty acids (1.56 gm/egg) and are rich in several micronutrients including vitamins and minerals, it would be worthwhile to include eggs in moderation as a part of a healthy eating pattern. This recommendation is particularly relevant when individual's intakes of nutrients are suboptimal, or with limited income and food access, and to help ensure dietary intake of sufficient nutrients in growing children and older adults.
\end{abstract}

Keywords: dietary cholesterol; LDL-cholesterol; cardiovascular disease (CVD); randomized control trials (RCT); observational studies; HMG CoA reductase; LDL and HDL

\section{Introduction}

Cardiovascular disease (CVD) is a leading cause of death in the US with approximately one in every four deaths occurring from heart diseases [1]. According to the CDC, 610,000 individuals die from CVD in the US [2]. The landmark of CVD is atherosclerosis, which is a chronic inflammatory condition instigated by deposition of cholesterol and fibrous tissues in the arterial walls which build up and eventually lead to narrowing and thickening or blocking of the arterial lumen. The inflammation regulates the plaque formation as well as the thrombotic complications of atherosclerosis [3]. The hypothesis that dietary cholesterol contributes to the risk of heart disease was initially suggested in 1968 and based on the research literature at the time [4,5]. Subsequently, the American Heart Association adopted a recommendation of limiting dietary cholesterol intake to $300 \mathrm{mg} / \mathrm{day}$ for healthy individuals in the United States, and with recommendations of restricting egg consumption to a maximum of three whole eggs per week [6]. However, the totality of scientific evidence and experimental data did not validate the hypothesis that dietary cholesterol increases blood cholesterol, and by extension increases the risk of CVD. Investigators have reported that increased intake of dietary cholesterol (exogenous) is associated with decreased synthesis of endogenous de novo cholesterol, possibly as a compensatory mechanism that keeps cholesterol homeostasis constant $[7,8]$. In fact, the 2015-2020 Dietary Guidelines for Americans removed the recommendations of setting a limit to the maximum intake of $300 \mathrm{mg} /$ day cholesterol. The Guidelines still advised eating as little as possible of 
dietary cholesterol while maintaining a healthy eating pattern. The following review will summarize the current literature regarding dietary cholesterol, blood cholesterol, saturated fatty acids and the risk of cardiovascular disease (CVD).

\section{Dietary Cholesterol Food Sources}

Dietary cholesterol is a main steroid from animal tissues. The main food sources include egg yolk, shrimp, beef, and pork, poultry, as well as cheese and butter. According to NHANES data, the top five food sources of cholesterol in the American population (2005-2006) are eggs, and mixed egg dishes, chicken, beef, and beef mixed dishes, burgers, and regular cheese [9]. There are two main sources that contribute to and make up the liver cholesterol pool, namely dietary cholesterol (exogenous), and de novo (endogenous) cholesterol which is synthesized in the liver or extra-hepatic tissue.

The relationship between dietary cholesterol and total plasma cholesterol has been reported to be linear based on observational cohort studies $[10,11]$. However, the limitation of the observational studies is the presence of confounding variables that may amplify positive or negative correlations as well as the existence of selection biases [12]. Additionally, the intake of dietary cholesterol is usually associated with an increased intake of saturated fatty acids which is documented to increase LDL Cholesterol and the risk of cardiovascular disease [13]. In fact, eggs are the only dietary source of cholesterol that is low in saturated fatty acid but is also nutrient-dense, economical and affordable. The average large whole egg (50 g), contains only $1.56 \mathrm{~g}$ of saturated fat, $1.83 \mathrm{~g}$ monounsaturated fat and $0.96 \mathrm{~g}$ polyunsaturated fat (Table 1). Egg yolk is also rich in dietary choline (147 mg) [14], which is an essential nutrient for human liver and muscle functions [15]. Choline intake is inadequate in 9 out of 10 American Adults [16]. Additionally, choline is essential for fetal and neonatal brain development [17-23], and inadequate intake during these critical developmental stages is associated with negative outcomes [24-26]. Also, inadequate choline in pregnant women increases the risk of neural tube defects in the offspring even in the era of folate fortification of food [27,28]. As noted, each egg (50 g) contains choline (147 mg, i.e., 34\% of the recommended daily Adequate Intake (AI) for adult female, and $26.5 \%$ AI for adult male) and is also rich in vitamin A (270 International Unit IU), and $80 \mu \mathrm{g}$ Retinol Activity Equivalents (RAE) i.e., 9\% RDA for adult male, 11\% RDA for adult female, lutein and zeaxanthin $(252 \mu \mathrm{g})$, folate $(24 \mu \mathrm{g}$ Dietary Folate Equivalents (DFE) i.e., 6\% RDA for adult male and female), phosphorous (99 mg, i.e., 15\% RDA for adult male and female), potassium (69 mg, i.e., 1\% AI for adult male and female) and calcium (28 mg, i.e., $2.8 \%$ RDA for adult male and female), [16,29]. In addition to these micronutrients, the egg is also rich in high-quality animal protein (6.28 g, i.e., $11 \%$ of the recommended RDA) (Table 1$)$. 
Table 1. Nutrient Composition of Most Commonly Consumed Cholesterol-Containing Foods

\begin{tabular}{|c|c|c|c|c|c|c|c|c|}
\hline \multirow{3}{*}{ Food Item } & \multirow{3}{*}{ Unit } & One Egg $^{a}$ & Beef $^{b}$ & Cheese $^{c}$ & Chicken $^{d}$ & Butter ${ }^{\mathrm{e}}$ & Shrimp ${ }^{f}$ & Two Eggs $\mathrm{g}$ \\
\hline & & per & per & per & per & per & Per & per \\
\hline & & $50 \mathrm{gm}$ & $100 \mathrm{gm}$ & $100 \mathrm{gm}$ & $100 \mathrm{gm}$ & 100 gm & $100 \mathrm{~g}$ & $100 \mathrm{gm}$ \\
\hline \multicolumn{9}{|l|}{ Nutrients } \\
\hline Energy & kcal & 72 & 674 & 393 & 215 & 714 & 62 & 143 \\
\hline Protein & $\mathrm{g}$ & 6.28 & 8.21 & 25 & 18.6 & & & 12.56 \\
\hline Total lipid (fat) & $\mathrm{g}$ & 4.75 & 70.9 & 32.14 & 15.06 & 78.57 & 13.27 & 9.51 \\
\hline Carbohydrate, by difference & $\mathrm{g}$ & 0.36 & - & - & - & - & 0.88 & 0.72 \\
\hline Fiber, total dietary & $\mathrm{g}$ & & - & - & - & - & - & 0 \\
\hline Sugars, total & $\mathrm{g}$ & 0.18 & - & - & - & - & - & 0.37 \\
\hline \multicolumn{9}{|l|}{ Minerals } \\
\hline Calcium, $\mathrm{Ca}$ & $\mathrm{mg}$ & 28 & 26 & 714 & 11 & - & 53 & 56 \\
\hline Iron, $\mathrm{Fe}$ & $\mathrm{mg}$ & 0.88 & 0.72 & - & 0.9 & - & 0.32 & 1.75 \\
\hline Magnesium, $\mathrm{Mg}$ & $\mathrm{mg}$ & 6 & 5 & - & 20 & - & - & 12 \\
\hline Phosphorus, $\mathrm{P}$ & $\mathrm{mg}$ & 99 & 61 & - & 147 & - & - & 198 \\
\hline Potassium, K & $\mathrm{mg}$ & 69 & 96 & - & 189 & - & - & 138 \\
\hline Sodium, $\mathrm{Na}$ & $\mathrm{mg}$ & 71 & 26 & 607 & 70 & - & 566 & 142 \\
\hline Zinc, Zn & $\mathrm{mg}$ & 0.65 & 0.82 & - & 1.31 & - & - & 1.29 \\
\hline Copper, $\mathrm{Cu}$ & $\mathrm{mg}$ & 0.04 & 0.03 & - & 0.048 & - & - & 0.072 \\
\hline Manganese, Mn & $\mathrm{mg}$ & 0.01 & - & - & 0.019 & - & - & 0.028 \\
\hline Selenium, Se & $\mu \mathrm{g}$ & 15.3 & 6.6 & - & 14.4 & - & - & 30.7 \\
\hline Fluoride, $\mathrm{F}$ & $\mu \mathrm{g}$ & 0.6 & - & - & - & - & - & 1.1 \\
\hline \multicolumn{9}{|l|}{ Vitamins } \\
\hline Vitamin $C$, total & $\mathrm{mg}$ & - & - & - & 1.6 & - & - & - \\
\hline Thiamin & $\mathrm{mg}$ & 0.02 & 0.03 & - & 0.06 & - & - & 0.04 \\
\hline Riboflavin & $\mathrm{mg}$ & 0.23 & 0.04 & - & 0.12 & - & - & 0.457 \\
\hline Niacin & $\mathrm{mg}$ & 0.04 & 1.44 & - & 6.801 & - & - & 0.075 \\
\hline Pantothenic acid & $\mathrm{mg}$ & 0.77 & 0.16 & - & 0.91 & - & - & 1.533 \\
\hline Vitamin B-6 & $\mathrm{mg}$ & 0.09 & 0.11 & - & 0.35 & - & - & 0.17 \\
\hline Folate, total & $\mu \mathrm{g}$ & 24 & - & - & 6 & - & - & 47 \\
\hline Choline, total & $\mathrm{mg}$ & 147 & - & - & 59.7 & - & - & 293.8 \\
\hline Vitamin B-12 & $\mu \mathrm{g}$ & 0.45 & 0.73 & - & 0.31 & - & - & 0.89 \\
\hline Vitamin B-12, added & $\mu \mathrm{g}$ & - & - & - & - & - & - & - \\
\hline Vitamin A, RAE & $\mu \mathrm{g}$ & 80 & - & - & 41 & - & - & 160 \\
\hline Carotene, beta & $\mu \mathrm{g}$ & - & - & - & - & - & - & - \\
\hline Carotene, alpha & $\mu \mathrm{g}$ & - & - & - & - & - & - & - \\
\hline Cryptoxanthin, beta & $\mu \mathrm{g}$ & 4 & - & - & - & - & - & 9 \\
\hline
\end{tabular}


Table 1. Cont

\begin{tabular}{|c|c|c|c|c|c|c|c|c|}
\hline \multirow{3}{*}{ Food Item } & \multirow{3}{*}{ Unit } & One Egg a & Beef $^{b}$ & Cheese $^{c}$ & Chicken $^{d}$ & Butter ${ }^{\mathrm{e}}$ & Shrimp ${ }^{f}$ & Two Eggs $\mathrm{g}$ \\
\hline & & per & per & per & per & per & Per & per \\
\hline & & $50 \mathrm{gm}$ & $100 \mathrm{gm}$ & $100 \mathrm{gm}$ & $100 \mathrm{gm}$ & $100 \mathrm{gm}$ & $100 \mathrm{~g}$ & $100 \mathrm{gm}$ \\
\hline \multicolumn{9}{|l|}{ Nutrients } \\
\hline Vitamin A, IU & IU & 270 & - & - & 137 & 2857 & 177 & 540 \\
\hline Lycopene & $\mu \mathrm{g}$ & - & - & - & - & - & - & \\
\hline Lutein + zeaxanthin & $\mu \mathrm{g}$ & 252 & - & - & - & - & - & 503 \\
\hline Vitamin E (alpha-tocopherol) & $\mathrm{mg}$ & 0.53 & - & - & 0.3 & - & - & 1.05 \\
\hline Vitamin E added & $\mathrm{mg}$ & - & - & - & - & - & - & - \\
\hline Tocopherol, beta & $\mathrm{mg}$ & 0.01 & - & - & - & - & - & 0.01 \\
\hline Tocopherol, gamma & $\mathrm{mg}$ & 0.25 & - & - & - & - & - & 0.5 \\
\hline Tocopherol, delta & $\mathrm{mg}$ & 0.03 & - & - & - & - & - & 0.06 \\
\hline Vitamin D (D2 + D3) & $\mu \mathrm{g}$ & 1 & 0.3 & - & 0.2 & - & - & 2 \\
\hline Vitamin D3 (cholecalciferol) & $\mu \mathrm{g}$ & 1 & 0.3 & - & - & - & - & 2 \\
\hline Vitamin D & IU & & 11 & 14 & 10 & - & - & 82 \\
\hline Vitamin K (phylloquinone) & $\mu \mathrm{g}$ & & 3.4 & - & 1.5 & - & - & 0.3 \\
\hline \multicolumn{9}{|l|}{ Lipids } \\
\hline${ }^{\mathrm{h}}$ Fatty acids, total saturated & g & 1.56 & 29.5 & 19.64 & 4.31 & 50 & 0 & 3.126 \\
\hline Fatty acids, total monounsaturated & $\mathrm{g}$ & 1.83 & 30.9 & - & 6.24 & - & - & 3.658 \\
\hline Fatty acids, total polyunsaturated & $\mathrm{g}$ & 0.96 & 2.56 & - & 3.23 & - & - & 1.911 \\
\hline Fatty acids, trans & $\mathrm{g}$ & 0.02 & & - & 0.097 & - & - & 0.038 \\
\hline${ }^{\mathrm{i}}$ Cholesterol & $\mathrm{mg}$ & 186 & 99 & 107 & 75 & 214 & 124 & 372 \\
\hline \multicolumn{9}{|l|}{ Amino Acids } \\
\hline Tryptophan & $\mathrm{g}$ & 0.08 & 0.05 & - & 0.207 & - & - & 0.167 \\
\hline Threonine & $\mathrm{g}$ & 0.28 & 0.33 & - & 0.767 & - & - & 0.556 \\
\hline Isoleucine & $\mathrm{g}$ & 0.34 & 0.37 & - & 0.924 & - & - & 0.671 \\
\hline Leucine & $\mathrm{g}$ & 0.54 & 0.65 & - & 1.35 & - & - & 1.086 \\
\hline Lysine & $\mathrm{g}$ & 0.46 & 0.69 & - & 1.509 & - & - & 0.912 \\
\hline Methionine & $\mathrm{g}$ & 0.19 & 0.21 & - & 0.493 & - & - & 0.38 \\
\hline Cystine & $\mathrm{g}$ & 0.14 & 0.11 & - & 0.249 & - & - & 0.272 \\
\hline Phenylalanine & $\mathrm{g}$ & 0.34 & 0.32 & - & 0.721 & - & - & 0.68 \\
\hline Tyrosine & $\mathrm{g}$ & 0.25 & 0.26 & - & 0.597 & - & - & 0.499 \\
\hline Valine & $\mathrm{g}$ & 0.43 & 0.41 & - & 0.902 & - & - & 0.858 \\
\hline Arginine & $\mathrm{g}$ & 0.41 & 0.53 & - & 1.169 & - & - & 0.82 \\
\hline Histidine & $\mathrm{g}$ & 0.15 & 0.26 & - & 0.544 & - & - & 0.309 \\
\hline Alanine & $\mathrm{g}$ & 0.37 & 0.5 & - & 1.089 & - & - & 0.735 \\
\hline Aspartic acid & $\mathrm{g}$ & 0.66 & 0.75 & - & 1.659 & - & - & 1.329 \\
\hline Glutamic acid & $\mathrm{g}$ & 0.84 & 1.23 & - & 2.714 & - & - & 1.673 \\
\hline
\end{tabular}


Table 1. Cont.

\begin{tabular}{|c|c|c|c|c|c|c|c|c|}
\hline \multirow{3}{*}{ Food Item } & \multirow{3}{*}{ Unit } & One Egg $^{a}$ & Beef $^{b}$ & Cheese $^{c}$ & Chicken $^{d}$ & Butter ${ }^{e}$ & Shrimp ${ }^{f}$ & Two Eggs \\
\hline & & per & per & per & per & per & Per & per \\
\hline & & $50 \mathrm{gm}$ & $100 \mathrm{gm}$ & $100 \mathrm{gm}$ & $100 \mathrm{gm}$ & $100 \mathrm{gm}$ & $100 \mathrm{~g}$ & $100 \mathrm{gm}$ \\
\hline \multicolumn{9}{|l|}{ Nutrients } \\
\hline Glycine & $\mathrm{g}$ & 0.22 & 0.5 & - & 1.223 & - & - & 0.432 \\
\hline Proline & $\begin{array}{l}0 \\
\mathrm{~g}\end{array}$ & 0.26 & 0.39 & - & 0.911 & - & - & 0.512 \\
\hline Serine & $\mathrm{g}$ & 0.49 & 0.32 & - & 0.657 & - & - & 0.971 \\
\hline Hydroxyproline & $\mathrm{g}$ & & 0.09 & - & - & - & - & - \\
\hline
\end{tabular}

a Egg: the reference is one large eggs $(50 \mathrm{~g}), 01123$, egg, whole, raw, fresh. ${ }^{\mathrm{b}}$ Beef reference is retail cut beef, 13019 , beef, retail cuts, separable fat, raw; ${ }^{\mathrm{c}} \mathrm{Cheese,} \mathrm{reference} \mathrm{is} \mathrm{natural} \mathrm{cheese,}$ 45352301, natural cheese UPC: 049646936410 ; $^{\mathrm{d}}$ chicken: the reference is 05006, chicken, broilers or fryers, meat, and skin, raw; ${ }^{\mathrm{e}}$ Butter: the reference is unsalted butter, 45118176 , White rose, unsalted butter, UPC: 074807101161 ; ${ }^{\mathrm{f}}$ Shrimp: the reference is shrimp raw medium-UCP $=041625114505 ; \mathrm{g}$ eggs: the reference is two large eggs (50 $\mathrm{g}$ each for total of $100 \mathrm{~g}$ ), 01123 , egg, whole, raw, fresh. ${ }^{\text {h }}$ Saturated fat content is in bold font, and ${ }^{\mathrm{i}}$ cholesterol content is in bold. Data obtained from the USDA National Nutrient Database for Standard Reference 1 April 2018 Software v.3.9.4 2018-05-02 [14]. 


\section{Cholesterol Homeostasis}

Cholesterol, a major sterol in animal tissues, has a significant function in the human body. Cholesterol is a structural component of cell membranes and plays an integral role in membrane fluidity. Cholesterol is also important in the synthesis of lipid rafts which are needed for protein sorting, cellular signaling, and apoptosis [30]. The characteristic structural feature of cholesterol is a fused four hydrocarbon ring referred to as a steroid nucleus, and a hydrocarbon tail consisting of eight hydrocarbon chain [31]. The cholesterol ring is the precursor of steroid hormones including estrogen, progesterone, testosterone, as well as vitamin D. As a hydrophobic molecule, cholesterol is transported in the blood via spherical macromolecules in the plasma termed lipoproteins including chylomicrons, VLDL, LDL, and HDL. The lipoproteins consist of a neutral lipid core containing cholesteryl ester and triacylglycerol surrounded by amphipathic apoproteins, phospholipids and non-esterified cholesterol. As such, the LDL particles transport cholesterol to peripheral tissues, and thus if the LDL-cholesterol is elevated, lipids can deposit in the arterial lumen leading to plaque formation, and thickening or narrowing of the blood vessel, the hallmark of atherosclerosis. On the other hand, HDL is responsible for the reverse cholesterol transport from peripheral tissues to the liver for bile acid synthesis, and steroid synthesis or for disposal of cholesterol ring via bile. As mentioned earlier, blood cholesterol is derived from two sources, exogenous dietary cholesterol and endogenous de novo synthesized cholesterol, and there is a balance and negative feedback to maintain cholesterol homeostasis. Endogenous cholesterol is synthesized by all cells and tissues, but predominantly in the liver, intestine and reproductive organs [32]. The rate-limiting and key regulatory step in endogenous cholesterol synthesis is mediated via 3-hydroxy-3-methylglutaryl CoA Reductase (HMG CoA Reductase), which reduces HMG CoA molecules to mevalonate, in the presence of NADPH as a reducing agent. Expression of HMG CoA reductase is inhibited by cholesterol as well as by statin drugs (atorvastatin, lovastatin, and Simvastatin). Thus, to maintain cholesterol balance, if dietary cholesterol absorption is increased, the endogenous synthesis is decreased [33]. The autoregulation of cholesterol synthesis encompasses control of HMG-CoA reductase by two mechanisms: (a) Feedback loop via cholesterol (which is referred to as bulk control), as well as (b) feedback loop via oxysterols, which functions to prevent accumulation of sterol intermediates and to fine tune the cholesterol regulation [34]. At the cellular level, cholesterol homeostasis is orchestrated by several regulatory transcriptional factor networks including the sterol regulatory element binding protein (SREBP), which regulates the biosynthesis and uptake of cholesterol as well as the liver X Receptor (LXR) family which regulates the excretion of excess cholesterol [35-37]. Another level of regulation is contributed by the farnesoid X receptor (FXR) which regulates bile acid metabolism [35,38-40].

\section{Dietary Cholesterol and Cardiovascular Disease (CVD) Risk}

\subsection{Animal Models Studies}

Guinea pigs are an ideal animal model to study human lipoprotein metabolism because they are LDL animals, they carry cholesterol in the LDL fraction, and they have CETP (Cholesteryl Ester Transfer Protein) similar to humans. Thus, the lipoprotein metabolism and remodeling is similar to humans. Lin et al., evaluated the cholesterol and lipoprotein metabolism in guinea pigs fed 0 dietary cholesterol (control), 0.08 (equivalent to $600 \mathrm{mg} /$ day in human), 0.17 (equivalent to $1275 \mathrm{mg}$ /day in human) or $0.33 \%$ dietary cholesterol (equivalent to $2475 \mathrm{mg} /$ day in human) [8,41,42]. The authors reported a dose-response relationship between intake of dietary cholesterol and plasma LDL cholesterol. This effect led to decreased synthesis of endogenous cholesterol as evidenced by a reduction in HMG CoA reductase, the rate-limiting enzyme and commitment step in cholesterol synthesis, as a compensatory mechanism. The hepatic LDL receptor numbers also decreased as cholesterol concentration increased. Plasma cholesterol increased with intake of $0.17 \%$ and $0.33 \%$ cholesterol and with saturated fatty acid intake [8]. Similar to humans, guinea pigs have individualized response to dietary cholesterol, emphasizing the notion that these animals could be hypo-responders 
or hyper-responders to dietary cholesterol [43]. Indeed, studies in humans have demonstrated that individuals could be hypo-responders or hyper-responders to dietary cholesterol [44]. Studies conducted in 1913 in rabbits showed that dietary cholesterol in rabbits induces atherosclerosis [45]. In mice deficient in Apolipoprotein E, animals fed either a control diet (AIN-93) or a diet containing $0.2 \mathrm{~g}$ cholesterol or $0.2 \mathrm{~g}$ oxysterol, showed an increase in liver and serum levels but the dietary cholesterol did not promote atherosclerosis and did not significantly accumulate in the aorta [46].

\subsection{Human Studies}

\subsubsection{Observational Studies}

In 1971, Kannel et al. reported that serum cholesterol was associated with increased risk of cardiovascular disease in the Framingham prospective cohort study [47]. Subsequently, risk factors for heart diseases were identified in this longitudinal study and the diet-heart disease hypothesis was established. For decades, the notion that elevated blood cholesterol is resultant from dietary intake cholesterol and saturated fatty acids were universally accepted. However, several follow-up studies showed no association between dietary cholesterol (egg consumption) and serum cholesterol, all-cause death, total coronary heart disease, or other heart disease problems such as angina pectoris or myocardial infarction [48]. Nevertheless, the recommendations of decreasing dietary cholesterol remained in effect. In 1988, Snowden reported that egg consumption was associated with all-cause mortality and coronary heart disease in females in a large cohort of California Seventh-Day Adventist adults [49]. However, Bechthold et al. conducted a meta-analysis study to investigate the relative risk between egg consumption and the risk of coronary heart disease (CHD) and stroke. There was no correlation between highest ( $75 \mathrm{~g})$ and lowest intake of eggs $(0 \mathrm{~g})$ and the risk of CHD or the risk of stroke, and there was no evidence that smaller studies had an outcome reporting bias. Furthermore, in a dose-response sub-analysis with increased increments of egg intake (50 g), there was no association between egg consumption, heart disease or stroke. However, there was a positive correlation between egg intake and the risk of heart failure [50]. On the contrary, reports from the two large prospective cohort studies, namely, the Nurses' Health Study (1980-1994) and the Health Professionals Follow-up Study (1986-1994), indicated that intake of dietary cholesterol consumed as one egg per day was not associated with increased risk of CHD in healthy men and women. Similar findings were summarized by Kritchevsky and colleagues [51,52]. In a recent study (2018), Li et al., reported that in Guangzhou Biobank Cohort Study, there were no statistical differences in the adjusted hazard ratio in all-cause mortality, mortality from CVD, ischemic heart disease or stroke and intakes of high egg consumption (7+ eggs per week) versus low egg consumption ( $<1$ egg per week), in a meta-analysis study design that included 28,024 participants without heart disease at the time of participation [53].

Regarding patients diagnosed with diabetes, investigators of the Health Professional Follow-up Study and Nurses' Health Study reported that in diabetic subjects, a high intake of eggs was correlated with increased risk in diabetic men [54]. Geiker et al. reviewed the literature regarding egg consumption in diabetic subjects and reported that dietary cholesterol and egg consumption was associated with increased risk of CVD [55]. However, Tran et al. did not find a correlation between egg consumption and CVD in diabetic patients [56]. In a cross-sectional study of 130,420 adult subjects aged 40-69 years in China, Shin and colleagues reported that a consumption of 7 eggs/week decreased the risk of metabolic syndrome (OR 0.77 CI, 0.70-0.84) compared with an intake of 1 egg/week [57]. Similarly, Park et al. analyzed Korea National Health and Nutrition Examination Survey (KNHANES) and found that the consumption of 4-6 eggs/week was associated with decreased risk of metabolic syndrome compared to the intake of $1 \mathrm{egg} / \mathrm{month}$ (OR 0.82, CI 0.71-0.95) [58]. However, in the US, most cohort studies reported to date suggest either a negative correlation between egg consumption in diabetic patients or no effect. For example, Djousse et al. followed a cohort of 20,703 men from the Physician Health Study and 36,295 women from the Women Health study for 20 years. The authors reported that consumption of 7 eggs/week was associated with increased risk of type 2 diabetes 
(Hazard Ratio 1.58, CI 1.25-2.01) in men and (1.77, CI 1.28-2.43) in women, compared to participants who consumed less than one egg per week. Additionally, the risk of heart diseases and mortality was also associated with consumption of 7 eggs/week (hazard ratio 2.01, CI: 1.26-3.20) compared to groups that consumed less than one egg per week among diabetic patients in the Physician Health Study [10]. The discrepancies of these findings could be attributable to confounding variables or differences in dietary patterns between populations. Some of the limitations of the observational studies are the inability to determine causality rather than reporting associations, possible selection bias, and the presence of confounding variables.

Based on the conflicting results, the limitations of the observational studies by confounding variables and selection bias, and a lack of causality identification; it seems that additional research methodology including meta-analysis or Mendelian Randomizations of genetically determined diabetes, metabolic syndrome, and heart disease are warranted in patients diagnosed with type 2 diabetes.

\subsubsection{Randomized Controlled Trial Studies}

A meta-analysis study of 17 randomized control trial studies conducted from 1974 to 1999 , revealed that the addition of $100 \mathrm{mg}$ of dietary cholesterol increased the total/HDL cholesterol ratio [59]. On the contrary, in a randomized controlled trial, Missimer et al. [60] found that the intake of two eggs per day did not have an adverse effect on heart disease biomarkers compared to the intake of oatmeal cereal. There was an increase in both HDL and LDL cholesterol, and therefore the LDL/HDL ratio, a marker to high risk of heart disease, remained constant, and thus the net cardiovascular risk did not increase. In the agreement, a randomized controlled trial (DIABEGG) compared the intake of a high-egg diet (2 eggs/day) with a low-egg diet (less than 2 eggs/day). The results showed that there were no differences in total cholesterol, LDL cholesterol or glycemic control in overweight and obese prediabetic or patients with type 2 diabetes [61]. Furthermore, to investigate the effects of egg on endothelial functions in patients with coronary heart disease, Katz et al., conducted a randomized, single-blind, cross-over, controlled trial for 6 weeks to compare breakfast containing 2 eggs, egg beaters, or a high carbohydrate breakfast [62]. The results indicated that there were no differences between groups in regards to lipids, flow-mediated dilation, systolic and diastolic blood pressure or body weight. Similarly, in a long-term randomized control trial, van der Made and colleagues [63] compared the consumption of lutein-enriched egg yolk in a buttermilk drink with a placebo group for one year. The authors reported that total cholesterol, LDL, and HDL cholesterol, as well as the total cholesterol to HDL cholesterol ratio, were not different between the two groups. Similar findings were reported in a randomized controlled trial comparing the intake of three eggs per day to Choline Bitartrate Supplement in healthy young men [64]. The study found that HDL-Cholesterol to LDL-cholesterol was maintained, indicating that exogenous cholesterol intake downregulated Sterol Regulatory element binding protein-2, and HMG-CoA reductase expression, thereby reducing endogenous cholesterol synthesis and thus maintaining the LDL/HDL ratio constant [64]. Blesso and colleagues conducted a randomized controlled trial $(n=40)$ where participants with metabolic syndrome were randomly assigned to either 3 whole eggs/day or yolk-free egg substitutes for 12 weeks, and both groups maintained a carbohydrate-restricted diet (25-30\%) [65]. The authors reported that participants who consumed whole eggs showed an improved lipid profile and decreased insulin resistance [65].

Several other randomized controlled trials indicated that egg consumption increased HDL cholesterol and decreased the risk factors associated with metabolic syndrome [66-68]. Along the same line, Fuller and colleagues reported that consumption of a high egg diet in pre-diabetes and patients with type 2 diabetes who had energy-restricted diets, had no adverse effect on blood glucose or glycated hemoglobin [61,69]. In a systematic review and meta-analysis, Berger et al. [70] compared the results from 19 randomized controlled trials of healthy individuals consuming dietary cholesterol (doses ranged between 501 and $1415 \mathrm{mg} /$ day), or control groups (0 to $415 \mathrm{mg} /$ day cholesterol). The authors reported a significant effect of dietary cholesterol on both LDL-Cholesterol as well 
as HDL-Cholesterol. As a result, the net LDL/HDL ratio was constant (0.17 net change) [70-93]. The increase in HDL cholesterol was pronounced with dietary cholesterol interventions doses between 650 and $900 \mathrm{mg} /$ day [82-93].

\section{Dietary Cholesterol, Saturated Fat, Trans Fatty Acids, and Cardiovascular Disease}

As shown in Table 1, most foods that contain high cholesterol content are also rich in animal-based saturated fatty acids (SFA). As such, for each $100 \mathrm{~g}$ beef (untrimmed) that contains $99 \mathrm{mg}$ cholesterol, it has 29.4 gm SFA; natural cheese, $107 \mathrm{mg}$ cholesterol, and 19 gm SFA; $214 \mathrm{mg}$ cholesterol, and 50 gm SFA; and chicken (meat and skin) contains $101 \mathrm{mg}$ cholesterol, and has $3.8 \mathrm{gm}$ SFA. The exceptions are egg and shrimp. Shrimp contains $124 \mathrm{mg}$ cholesterol and $0 \mathrm{~g} \mathrm{SFA}$, and one large egg (50 g) contains $186 \mathrm{mg}$ cholesterol and $1.56 \mathrm{~g}$ SFA (Table 1). While shrimp is arguably expensive, egg is an economical and nutrient-dense food item with high-quality protein which is convenient and affordable to low-income families and is a good source of nutrients for growing children and older adults.

A large body of literature documented the negative effects of saturated fatty acids on the development of CVD as reviewed by Yu and Hu 2018 [94]. Further, the American Heart Association reviewed the scientific evidence from prospective observational studies and randomized controlled trials and concluded that the replacement of dietary saturated fatty acids with polyunsaturated or monounsaturated fatty acids decreased the risk of CVD [95]. Trans-fatty acids are found naturally in a small amount in some meat and dairy products. However, most food consumption of trans-fatty acids is from manufactured hydrogenated unsaturated fatty acids. These partially hydrogenated trans-fatty acids that introduce at least one hydrogen bond in the trans configuration were originally developed to improve the quality and shelf life of baked goods and are used in margarine and commercial cooking. However, mounting evidence indicated that trans-fatty acids increased the risk of coronary heart disease mortality and cardiovascular disease incidence in a manner similar to saturated fatty acids [96-100]. As such, several European Countries introduced laws to limit the amount of trans-fatty acids in food [97]. In the United States, the FDA ruled that the content of trans fat should be included in the food label since 1990. The 2015-2020 Dietary Guidelines recommended limiting the intake of saturated fat and trans fat as part of a healthy eating pattern.

Thus, the totality of scientific evidence guided the 2010 and 2015 Dietary Guidelines for Americans and developed the recommendations to decrease intake of saturated fatty acids to less than $10 \%$ of calories and replacing it with monounsaturated and polyunsaturated fatty acids. Additionally, the American Heart Association recommends less than $7 \%$ of calories from saturated fatty acids. Fielding et al. found that an intervention with an intake of $600 \mathrm{mg}$ cholesterol with a diet high in the saturated fatty acids led to increased LDL cholesterol much more than when cholesterol was administered with polyunsaturated fatty acids [75]. As noted earlier, several of the high cholesterol foods are also rich in saturated fatty acids such as beef (untrimmed and with marble), natural cheese, and butter (Table 1 , and the USDA Nutrient Composition Database), and thus may increase the risk of CVD due to the saturated fatty acid content. The exceptions are shrimps (zero saturated fatty acids) and eggs (1.56 gm saturated fatty acids per large egg which accounts for $0.65 \%$ of calories).

\section{Conclusions}

The current literature does not support the notion that dietary cholesterol increases the risk of heart disease in a healthy individuals. However, there is an ample evidence that saturated fatty acids and trans-fats increase cardiovascular disease risk. The fact that dietary cholesterol is common in foods that are high in saturated fatty acids might have contributed to the hypothesis that dietary cholesterol is atherogenic. In contrast, eggs are affordable, rich in protein and micronutrients, nutrient-dense and low in saturated fatty acids. The healthy eating pattern can incorporate nutrient-dense, calorie controlled meals with balanced nutrients and a variety of colorful vegetables and fruits. The body of literature regarding dietary cholesterol and cardiovascular disease in patients diagnosed with diabetes is still inconclusive and warrants further research. 
Author Contributions: G.S. researched, designed, analyzed, interpreted the results and wrote the manuscript.

Funding: The investigator's work and publication costs are funded by an institutional start-up fund.

Conflicts of Interest: The authors declare no conflict of interest.

\section{References}

1. Centers for Disease Control and Prevention, and National Center for Health Statistics. Underlying Cause of Death 1999-2016 on CDC WONDER Online Database, Released 2017. Data Are from the Multiple Cause of Death Files, 1999-2016, as Compiled from Data Provided by the 57 Vital Statistics Jurisdictions through the Vital Statistics Cooperative Program. Available online: https://wonder.cdc.gov/wonder/help/ucd.html (accessed on 11 May 2018).

2. Ahmed, S.; Gul, S.; Zia-ul-Haq, M.; Riaz, M. Hypolipidemic effects of nimesulide and celecoxib in experimentally induced hypercholesterolemia in rabbits. Turk. J. Med. Sci. 2015, 45, 277-283. [CrossRef] [PubMed]

3. Espinola-Klein, C.; Gori, T.; Blankenberg, S.; Munzel, T. Inflammatory markers and cardiovascular risk in the metabolic syndrome. Front. Biosci. (Landmark Ed.) 2011, 16, 1663-1674. [CrossRef] [PubMed]

4. Dietschy, J.M.; Siperstein, M.D. Effect of cholesterol feeding and fasting on sterol synthesis in seventeen tissues of the rat. J. Lipid Res. 1967, 8, 97-104. [PubMed]

5. Wilson, J.D.; Lindsey, C.A.; Dietschy, J.M. Influence of dietary cholesterol on cholesterol metabolism. Ann. N. Y. Acad. Sci. 1968, 149, 808-821. [CrossRef] [PubMed]

6. Association, A.H. Diet and Heart Disease; American Heart Association: Dallas, TX, USA, 1968.

7. Hu, Y.W.; Zheng, L.; Wang, Q. Regulation of cholesterol homeostasis by liver X receptors. Clin. Chim. Acta 2010, 411, 617-625. [CrossRef] [PubMed]

8. Lin, E.C.; Fernandez, M.L.; McNamara, D.J. Dietary fat type and cholesterol quantity interact to affect cholesterol metabolism in guinea pigs. J. Nutr. 1992, 122, 2019-2029. [CrossRef] [PubMed]

9. Top Food Sources of Cholesterol among U.S Population, 2005-2006 NHANES. Available online: https: / / epi.grants.cancer.gov/diet/foodsources/cholesterol/table1.html (accessed on 10 May 2018).

10. Djousse, L.; Gaziano, J.M. Egg consumption in relation to cardiovascular disease and mortality: The Physicians' Health Study. Am. J. Clin. Nutr. 2008, 87, 964-969. [CrossRef] [PubMed]

11. McGill, H.C., Jr. The relationship of dietary cholesterol to serum cholesterol concentration and to atherosclerosis in man. Am. J. Clin. Nutr. 1979, 32 (Suppl. 12), 2664-2702. [CrossRef] [PubMed]

12. Song, J.W.; Chung, K.C. Observational studies: Cohort and case-control studies. Plast. Reconstr. Surg. 2010, 126, 2234-2242. [CrossRef] [PubMed]

13. Hu, F.B.; Manson, J.E.; Willett, W.C. Types of dietary fat and risk of coronary heart disease: A critical review. J. Am. Coll. Nutr. 2001, 20,5-19. [CrossRef] [PubMed]

14. USDA. United States Department of Agriculture National Nutrient Database for Standard Reference 1 April 2018 Software v.3.9.4 2018-05-02. Available online: https:/ / ndb.nal.usda.gov/ndb/search/list (accessed on 10 May 2018).

15. Clayton, Z.S.; Fusco, E.; Kern, M. Egg consumption and heart health: A review. Nutrition 2017, 37, 79-85. [CrossRef] [PubMed]

16. McNamara, D.J. The Fifty Year Rehabilitation of the Egg. Nutrients 2015, 7, 8716-8722. [CrossRef] [PubMed]

17. Zeisel, S.H. The fetal origins of memory: The role of dietary choline in optimal brain development. J. Pediatr. 2006, 149 (Suppl. 5), S131-S136. [CrossRef] [PubMed]

18. Zeisel, S.H. Choline: Critical role during fetal development and dietary requirements in adults. Annu. Rev. Nutr. 2006, 26, 229-250. [CrossRef] [PubMed]

19. Da Costa, K.A.; Niculescu, M.D.; Craciunescu, C.N.; Fischer, L.M.; Zeisel, S.H. Choline deficiency increases lymphocyte apoptosis and DNA damage in humans. Am. J. Clin. Nutr. 2006, 84, 88-94. [CrossRef] [PubMed]

20. Da Costa, K.A.; Kozyreva, O.G.; Song, J.; Galanko, J.A.; Fischer, L.M.; Zeisel, S.H. Common genetic polymorphisms affect the human requirement for the nutrient choline. FASEB J. 2006, 20, 1336-1344. [CrossRef] [PubMed]

21. Zeisel, S.H.; Niculescu, M.D. Perinatal choline influences brain structure and function. Nutr. Rev. 2006, 64, 197-203. [CrossRef] [PubMed] 
22. Cho, E.; Zeisel, S.H.; Jacques, P.; Selhub, J.; Dougherty, L.; Colditz, G.A.; Willett, W.C. Dietary choline and betaine assessed by food-frequency questionnaire in relation to plasma total homocysteine concentration in the Framingham Offspring Study. Am. J. Clin. Nutr. 2006, 83, 905-911. [CrossRef] [PubMed]

23. Niculescu, M.D.; Craciunescu, C.N.; Zeisel, S.H. Dietary choline deficiency alters global and gene-specific DNA methylation in the developing hippocampus of mouse fetal brains. FASEB J. 2006, 20, 43-49. [CrossRef] [PubMed]

24. Shapira, N. Modified egg as a nutritional supplement during peak brain development: A new target for fortification. Nutr. Health 2009, 20, 107-118. [CrossRef] [PubMed]

25. Leermakers, E.T.; Moreira, E.M.; Kiefte-de Jong, J.C.; Darweesh, S.K.; Visser, T.; Voortman, T.; Bautista, P.K.; Chowdhury, R.; Gorman, D.; Bramer, W.M.; et al. Effects of choline on health across the life course: A systematic review. Nutr. Rev. 2015, 73, 500-522. [CrossRef] [PubMed]

26. Ruxton, C. Value of eggs during pregnancy and early childhood. Nurs. Stand. 2013, 27, 41-50. [CrossRef] [PubMed]

27. Shaw, G.M.; Finnell, R.H.; Blom, H.J.; Carmichael, S.L.; Vollset, S.E.; Yang, W.; Ueland, P.M. Choline and risk of neural tube defects in a folate-fortified population. Epidemiology 2009, 20, 714-719. [CrossRef] [PubMed]

28. Shaw, G.M.; Carmichael, S.L.; Yang, W.; Selvin, S.; Schaffer, D.M. Periconceptional dietary intake of choline and betaine and neural tube defects in offspring. Am. J. Epidemiol. 2004, 160, 102-109. [CrossRef] [PubMed]

29. USDA National Nutrient Database for Standard Reference 1 April 2018 Software v.3.9.4 2018-05-02 AM. 2018, Whole Egg, Raw. Available online: https:/ /ndb.nal.usda.gov/ndb/foods/show/01123 (accessed on 2 June 2018).

30. Jacobson, K.; Mouritsen, O.G.; Anderson, R.G. Lipid rafts: At a crossroad between cell biology and physics. Nat. Cell Biol. 2007, 9, 7-14. [CrossRef] [PubMed]

31. Poian, A.T.D.; Castanho, M.A.R.B. Integrative Human Biochemistry: A Textbook for Medical Biochemistry; Springer: New York, NY, USA, 2015.

32. Harvey, R.A.; Ferrier, D. (Eds.) Biochemistry, Lippincott Illustrated Reviews, 5th ed.; Lippincott Williams and Wilkins: Philadelphia, PA, USA, 2011.

33. Jones, P.J. Dietary cholesterol and the risk of cardiovascular disease in patients: A review of the Harvard Egg Study and other data. Int. J. Clin. Pract. 2009, 63, 1-8. [CrossRef] [PubMed]

34. Fakheri, R.J.; Javitt, N.B. Autoregulation of cholesterol synthesis: Physiologic and pathophysiologic consequences. Steroids 2011, 76, 211-215. [CrossRef] [PubMed]

35. Chiang, J.Y.; Kimmel, R.; Stroup, D. Regulation of cholesterol $7 \alpha$-hydroxylase gene (CYP7A1) transcription by the liver orphan receptor (LXR $\alpha)$. Gene 2001, 262, 257-265. [CrossRef]

36. Ahlberg, C.M.; Schiermiester, L.N.; Howard, T.J.; Calkins, C.R.; Spangler, M.L. Genome wide association study of cholesterol and poly- and monounsaturated fatty acids, protein, and mineral content of beef from crossbred cattle. Meat Sci. 2014, 98, 804-814. [CrossRef] [PubMed]

37. Calkin, A.C.; Tontonoz, P. Transcriptional integration of metabolism by the nuclear sterol-activated receptors LXR and FXR. Nat. Rev. Mol. Cell Boil. 2012, 13, 213-224. [CrossRef] [PubMed]

38. Chiang, J.Y.L.; Ferrell, J.M. Bile Acid Metabolism in Liver Pathobiology. Gene Expr. 2018, 18, 71-87. [CrossRef] [PubMed]

39. Qi, Y.; Jiang, C.; Cheng, J.; Krausz, K.W.; Li, T.; Ferrell, J.M.; Gonzalez, F.J.; Chiang, J.Y. Bile acid signaling in lipid metabolism: Metabolomic and lipidomic analysis of lipid and bile acid markers linked to anti-obesity and anti-diabetes in mice. Biochim. Biophys. Acta 2015, 1851, 19-29. [CrossRef] [PubMed]

40. Liu, X.; Cui, L.; Wang, A.; Wang, X.; Song, Q.; Li, S.; Shi, J.; Zhao, X.; Chen, S.; Du, X.; et al. Cumulative Exposure to Ideal Cardiovascular Health and Incident Diabetes in a Chinese Population: The Kailuan Study. J. Am. Heart Assoc. 2016, 5, e004132. [CrossRef] [PubMed]

41. Lin, E.C.; Fernandez, M.L.; Tosca, M.A.; McNamara, D.J. Regulation of hepatic LDL metabolism in the guinea pig by dietary fat and cholesterol. J. Lipid Res. 1994, 35, 446-457. [PubMed]

42. Lin, E.C.; Fernandez, M.L.; McNamara, D.J. High density lipoprotein metabolism is altered by dietary cholesterol but not fat saturation in guinea pigs. Atherosclerosis 1995, 112, 161-175. [CrossRef]

43. Fernandez, M.L.; Lin, E.C.; Trejo, A.; McNamara, D.J. Prickly pear (Opuntia sp.) pectin reverses low density lipoprotein receptor suppression induced by a hypercholesterolemic diet in guinea pigs. J. Nutr. 1992, 122, 2330-2340. [CrossRef] [PubMed] 
44. McNamara, D.J.; Kolb, R.; Parker, T.S.; Batwin, H.; Samuel, P.; Brown, C.D.; Ahrens, E.H., Jr. Heterogeneity of cholesterol homeostasis in man. Response to changes in dietary fat quality and cholesterol quantity. J. Clin. Investig. 1987, 79, 1729-1739. [CrossRef] [PubMed]

45. Finking, G.; Hanke, H. Nikolaj Nikolajewitsch Anitschkow (1885-1964) established the cholesterol-fed rabbit as a model for atherosclerosis research. Atherosclerosis 1997, 135, 1-7. [CrossRef]

46. Ando, M.; Tomoyori, H.; Imaizumi, K. Dietary cholesterol-oxidation products accumulate in serum and liver in apolipoprotein E-deficient mice, but do not accelerate atherosclerosis. Br. J. Nutr. 2002, 88, 339-345. [CrossRef] [PubMed]

47. Kannel, W.B.; Castelli, W.P.; Gordon, T.; McNamara, P.M. Serum cholesterol, lipoproteins, and the risk of coronary heart disease. The Framingham study. Ann. Intern. Med. 1971, 74, 1-12. [CrossRef] [PubMed]

48. Dawber, T.R.; Nickerson, R.J.; Brand, F.N.; Pool, J. Eggs, serum cholesterol, and coronary heart disease. Am. J. Clin. Nutr. 1982, 36, 617-625. [CrossRef] [PubMed]

49. Snowdon, D.A. Animal product consumption and mortality because of all causes combined, coronary heart disease, stroke, diabetes, and cancer in Seventh-day Adventists. Am. J. Clin. Nutr. 1988, 48 (Suppl. 3), 739-748. [CrossRef] [PubMed]

50. Bechthold, A.; Boeing, H.; Schwedhelm, C.; Hoffmann, G.; Knuppel, S.; Iqbal, K.; De Henauw, S.; Michels, N.; Devleesschauwer, B.; Schlesinger, S.; et al. Food groups and risk of coronary heart disease, stroke and heart failure: A systematic review and dose-response meta-analysis of prospective studies. Crit. Rev. Food Sci. Nutr. 2017, 1-20. [CrossRef] [PubMed]

51. Kritchevsky, S.B.; Kritchevsky, D. Egg consumption and coronary heart disease: An epidemiologic overview. J. Am. Coll. Nutr. 2000, 19 (Suppl. 5), 549S-555S. [CrossRef] [PubMed]

52. Kritchevsky, S.B. A review of scientific research and recommendations regarding eggs. J. Am. Coll. Nutr. 2004, 23 (Suppl. 6), 596S-600S. [CrossRef] [PubMed]

53. Xu, L.; Lam, T.H.; Jiang, C.Q.; Zhang, W.S.; Zhu, F.; Jin, Y.L.; Woo, J.; Cheng, K.K.; Thomas, G.N. Egg consumption and the risk of cardiovascular disease and all-cause mortality: Guangzhou Biobank Cohort Study and meta-analyses. Eur. J. Nutr. 2018, 1-12. [CrossRef] [PubMed]

54. Hu, F.B.; Stampfer, M.J.; Rimm, E.B.; Manson, J.E.; Ascherio, A.; Colditz, G.A.; Rosner, B.A.; Spiegelman, D.; Speizer, F.E.; Sacks, F.M.; et al. A prospective study of egg consumption and risk of cardiovascular disease in men and women. JAMA 1999, 281, 1387-1394. [CrossRef] [PubMed]

55. Geiker, N.R.W.; Larsen, M.L.; Dyerberg, J.; Stender, S.; Astrup, A. Egg consumption, cardiovascular diseases and type 2 diabetes. Eur. J. Clin. Nutr. 2018, 72, 44-56. [CrossRef] [PubMed]

56. Tran, N.L.; Barraj, L.M.; Heilman, J.M.; Scrafford, C.G. Egg consumption and cardiovascular disease among diabetic individuals: A systematic review of the literature. Diabetes Metab. Syndr. Obes. 2014, 7, 121-137. [CrossRef] [PubMed]

57. Shin, S.; Lee, H.W.; Kim, C.E.; Lim, J.; Lee, J.K.; Lee, S.A.; Kang, D. Egg Consumption and Risk of Metabolic Syndrome in Korean Adults: Results from the Health Examinees Study. Nutrients 2017, 9, 687. [CrossRef] [PubMed]

58. Park, S.J.; Jung, J.H.; Choi, S.W.; Lee, H.J. Association between Egg Consumption and Metabolic Disease. Korean J. Food Sci. Anim. Resour. 2018, 38, 209-223. [PubMed]

59. Weggemans, R.M.; Zock, P.L.; Katan, M.B. Dietary cholesterol from eggs increases the ratio of total cholesterol to high-density lipoprotein cholesterol in humans: A meta-analysis. Am. J. Clin. Nutr. 2001, 73, 885-891. [CrossRef] [PubMed]

60. Missimer, A.; DiMarco, D.M.; Andersen, C.J.; Murillo, A.G.; Vergara-Jimenez, M.; Fernandez, M.L. Consuming Two Eggs per Day, as Compared to an Oatmeal Breakfast, Decreases Plasma Ghrelin while Maintaining the LDL/HDL Ratio. Nutrients 2017, 9, 89. [CrossRef] [PubMed]

61. Fuller, N.R.; Caterson, I.D.; Sainsbury, A.; Denyer, G.; Fong, M.; Gerofi, J.; Baqleh, K.; Williams, K.H.; Lau, N.S.; Markovic, T.P. The effect of a high-egg diet on cardiovascular risk factors in people with type 2 diabetes: The Diabetes and Egg (DIABEGG) study-a 3-mo randomized controlled trial. Am. J. Clin. Nutr. 2015, 101, 705-713. [CrossRef] [PubMed]

62. Katz, D.L.; Gnanaraj, J.; Treu, J.A.; Ma, Y.; Kavak, Y.; Njike, V.Y. Effects of egg ingestion on endothelial function in adults with coronary artery disease: A randomized, controlled, crossover trial. Am. Heart J. 2015, 169, 162-169. [CrossRef] [PubMed] 
63. Van der Made, S.M.; Kelly, E.R.; Berendschot, T.T.; Kijlstra, A.; Lutjohann, D.; Plat, J. Consuming a buttermilk drink containing lutein-enriched egg yolk daily for 1 year increased plasma lutein but did not affect serum lipid or lipoprotein concentrations in adults with early signs of age-related macular degeneration. J. Nutr. 2014, 144, 1370-1377. [CrossRef] [PubMed]

64. Lemos, B.S.; Medina-Vera, I.; Blesso, C.N.; Fernandez, M.L. Intake of 3 Eggs per Day When Compared to a Choline Bitartrate Supplement, Downregulates Cholesterol Synthesis without Changing the LDL/HDL Ratio. Nutrients 2018, 10, 258. [CrossRef] [PubMed]

65. Blesso, C.N.; Andersen, C.J.; Barona, J.; Volk, B.; Volek, J.S.; Fernandez, M.L. Effects of carbohydrate restriction and dietary cholesterol provided by eggs on clinical risk factors in metabolic syndrome. J. Clin. Lipidol. 2013, 7, 463-471. [CrossRef] [PubMed]

66. Mutungi, G.; Waters, D.; Ratliff, J.; Puglisi, M.; Clark, R.M.; Volek, J.S.; Fernandez, M.L. Eggs distinctly modulate plasma carotenoid and lipoprotein subclasses in adult men following a carbohydrate-restricted diet. J. Nutr. Biochem. 2010, 21, 261-267. [CrossRef] [PubMed]

67. Mutungi, G.; Ratliff, J.; Puglisi, M.; Torres-Gonzalez, M.; Vaishnav, U.; Leite, J.O.; Quann, E.; Volek, J.S.; Fernandez, M.L. Dietary cholesterol from eggs increases plasma HDL cholesterol in overweight men consuming a carbohydrate-restricted diet. J. Nutr. 2008, 138, 272-276. [CrossRef] [PubMed]

68. Ratliff, J.C.; Mutungi, G.; Puglisi, M.J.; Volek, J.S.; Fernandez, M.L. Eggs modulate the inflammatory response to carbohydrate restricted diets in overweight men. Nutr. Metab. 2008, 5, 6. [CrossRef] [PubMed]

69. Fuller, N.R.; Sainsbury, A.; Caterson, I.D.; Denyer, G.; Fong, M.; Gerofi, J.; Leung, C.; Lau, N.S.; Williams, K.H.; Januszewski, A.S.; et al. Effect of a high-egg diet on cardiometabolic risk factors in people with type 2 diabetes: The Diabetes and Egg (DIABEGG) Study-randomized weight-loss and follow-up phase. Am. J. Clin. Nutr. 2018, 107, 921-931. [CrossRef] [PubMed]

70. Berger, S.; Raman, G.; Vishwanathan, R.; Jacques, P.F.; Johnson, E.J. Dietary cholesterol and cardiovascular disease: A systematic review and meta-analysis. Am. J. Clin. Nutr. 2015, 102, 276-294. [CrossRef] [PubMed]

71. Blesso, C.N.; Fernandez, M.L. Dietary Cholesterol, Serum Lipids, and Heart Disease: Are Eggs Working for or Against You? Nutrients 2018, 10, 426. [CrossRef] [PubMed]

72. Nissinen, M.J.; Gylling, H.; Miettinen, T.A. Responses of surrogate markers of cholesterol absorption and synthesis to changes in cholesterol metabolism during various amounts of fat and cholesterol feeding among healthy men. Br. J. Nutr. 2008, 99, 370-378. [CrossRef] [PubMed]

73. Bowman, M.P.; Van Doren, J.; Taper, L.J.; Thye, F.W.; Ritchey, S.J. Effect of dietary fat and cholesterol on plasma lipids and lipoprotein fractions in normolipidemic men. J. Nutr 1988, 118, 555-560. [CrossRef] [PubMed]

74. Clifton, P.M.; Kestin, M.; Abbey, M.; Drysdale, M.; Nestel, P.J. Relationship between sensitivity to dietary fat and dietary cholesterol. Arteriosclerosis 1990, 10, 394-401. [CrossRef] [PubMed]

75. Fielding, C.J.; Havel, R.J.; Todd, K.M.; Yeo, K.E.; Schloetter, M.C.; Weinberg, V.; Frost, P.H. Effects of dietary cholesterol and fat saturation on plasma lipoproteins in an ethnically diverse population of healthy young men. J. Clin. Investig. 1995, 95, 611-618. [CrossRef] [PubMed]

76. Chotivichien, S.; Arab, L.; Prasithsirikul, W.; Manosuthi, W.; Sinawat, S.; Detels, R. Effect of nutritional counseling on low-density lipoprotein cholesterol among Thai HIV-infected adults receiving antiretroviral therapy. AIDS Care 2016, 28, 257-265. [CrossRef] [PubMed]

77. Flaim, E.; Ferreri, L.F.; Thye, F.W.; Hill, J.E.; Ritchey, S.J. Plasma lipid and lipoprotein cholesterol concentrations in adult males consuming normal and high cholesterol diets under controlled conditions. Am. J. Clin. Nutr. 1981, 34, 1103-1108. [CrossRef] [PubMed]

78. Flynn, M.A.; Nolph, G.B.; Osio, Y.; Sun, G.Y.; Lanning, B.; Krause, G.; Dally, J.C. Serum lipids and eggs. J. Am. Diet. Assoc. 1986, 86, 1541-1548. [PubMed]

79. Flynn, M.A.; Nolph, G.B.; Flynn, T.C.; Kahrs, R.; Krause, G. Effect of dietary egg on human serum cholesterol and triglycerides. Am. J. Clin. Nutr. 1979, 32, 1051-1057. [CrossRef] [PubMed]

80. Ginsberg, H.N.; Karmally, W.; Siddiqui, M.; Holleran, S.; Tall, A.R.; Rumsey, S.C.; Deckelbaum, R.J.; Blaner, W.S.; Ramakrishnan, R. A dose-response study of the effects of dietary cholesterol on fasting and postprandial lipid and lipoprotein metabolism in healthy young men. Arterioscler. Thromb. Vasc. Biol. 1994, 14, 576-586. [CrossRef] 
81. Ginsberg, H.N.; Karmally, W.; Siddiqui, M.; Holleran, S.; Tall, A.R.; Blaner, W.S.; Ramakrishnan, R. Increases in dietary cholesterol are associated with modest increases in both LDL and HDL cholesterol in healthy young women. Arterioscler. Thromb. Vasc. Biol. 1995, 15, 169-178. [CrossRef] [PubMed]

82. Greene, C.M.; Zern, T.L.; Wood, R.J.; Shrestha, S.; Aggarwal, D.; Sharman, M.J.; Volek, J.S.; Fernandez, M.L. Maintenance of the LDL cholesterol:HDL cholesterol ratio in an elderly population given a dietary cholesterol challenge. J. Nutr. 2005, 135, 2793-2798. [CrossRef] [PubMed]

83. Herron, K.L.; Lofgren, I.E.; Sharman, M.; Volek, J.S.; Fernandez, M.L. High intake of cholesterol results in less atherogenic low-density lipoprotein particles in men and women independent of response classification. Metabolism 2004, 53, 823-830. [CrossRef] [PubMed]

84. Herron, K.L.; Fernandez, M.L. Are the current dietary guidelines regarding egg consumption appropriate? J. Nutr. 2004, 134, 187-190. [CrossRef] [PubMed]

85. Herron, K.L.; Vega-Lopez, S.; Conde, K.; Ramjiganesh, T.; Shachter, N.S.; Fernandez, M.L. Men classified as hypo- or hyperresponders to dietary cholesterol feeding exhibit differences in lipoprotein metabolism. J. Nutr. 2003, 133, 1036-1042. [CrossRef] [PubMed]

86. Herron, K.L.; Vega-Lopez, S.; Conde, K.; Ramjiganesh, T.; Roy, S.; Shachter, N.S.; Fernandez, M.L. Pre-menopausal women, classified as hypo- or hyperresponders, do not alter their LDL/HDL ratio following a high dietary cholesterol challenge. J. Am. Coll. Nutr. 2002, 21, 250-258. [CrossRef] [PubMed]

87. Johnson, C.; Greenland, P. Effects of exercise, dietary cholesterol, and dietary fat on blood lipids. Arch. Intern. Med. 1990, 150, 137-141. [CrossRef] [PubMed]

88. Kestin, M.; Clifton, P.M.; Rouse, I.L.; Nestel, P.J. Effect of dietary cholesterol in normolipidemic subjects is not modified by nature and amount of dietary fat. Am. J. Clin. Nutr. 1989, 50, 528-532. [CrossRef] [PubMed]

89. Quig, D.W.; Thye, F.W.; Ritchey, S.J.; Herbert, W.G.; Clevidence, B.A.; Reynolds, L.K.; Smith, M.C. Effects of short-term aerobic conditioning and high cholesterol feeding on plasma total and lipoprotein cholesterol levels in sedentary young men. Am. J. Clin. Nutr. 1983, 38, 825-834. [CrossRef] [PubMed]

90. Reaven, G.M.; Abbasi, F.; Bernhart, S.; Coulston, A.; Darnell, B.; Dashti, N.; Kim, H.; Kulkarni, K.; Lamendola, C.; McLaughlin, T.; et al. Insulin resistance, dietary cholesterol, and cholesterol concentration in postmenopausal women. Metabolism 2001, 50, 594-597. [CrossRef] [PubMed]

91. Kehoe, R. Increase in egg intake minimally affects blood cholesterol level. Poult. Advis. 1995, 28, 31-34.

92. Duane, W.C. Effects of soybean protein and very low dietary cholesterol on serum lipids, biliary lipids, and fecal sterols in humans. Metabolism 1999, 48, 489-494. [CrossRef]

93. Vorster, H.H.; Benade, A.J.; Barnard, H.C.; Locke, M.M.; Silvis, N.; Venter, C.S.; Smuts, C.M.; Engelbrecht, G.P.; Marais, M.P. Egg intake does not change plasma lipoprotein and coagulation profiles. Am. J. Clin. Nutr. 1992, 55, 400-410. [CrossRef] [PubMed]

94. Yu, E.; Hu, F.B. Dairy Products, Dairy Fatty Acids, and the Prevention of Cardiometabolic Disease: A Review of Recent Evidence. Curr. Atheroscler. Rep. 2018, 20, 24. [CrossRef] [PubMed]

95. Sacks, F.M.; Lichtenstein, A.H.; Wu, J.H.Y.; Appel, L.J.; Creager, M.A.; Kris-Etherton, P.M.; Miller, M.; Rimm, E.B.; Rudel, L.L.; Robinson, J.G.; et al. Dietary Fats and Cardiovascular Disease: A Presidential Advisory From the American Heart Association. Circulation 2017, 136, e1-e23. [CrossRef] [PubMed]

96. Wu, J.H.; Zheng, M.; Catterall, E.; Downs, S.; Thomas, B.; Veerman, L.; Barendregt, J.J. Contribution of Trans-Fatty Acid Intake to Coronary Heart Disease Burden in Australia: A Modelling Study. Nutrients 2017, 9, 77. [CrossRef] [PubMed]

97. Wilczek, M.M.; Olszewski, R.; Krupienicz, A. Trans-Fatty Acids and Cardiovascular Disease: Urgent Need for Legislation. Cardiology 2017, 138, 254-258. [CrossRef] [PubMed]

98. Lemaitre, R.N.; King, I.B.; Mozaffarian, D.; Sotoodehnia, N.; Siscovick, D.S. Trans-fatty acids and sudden cardiac death. Atheroscler. Suppl. 2006, 7, 13-15. [CrossRef] [PubMed]

99. Mozaffarian, D.; Aro, A.; Willett, W.C. Health effects of trans-fatty acids: Experimental and observational evidence. Eur. J. Clin. Nutr. 2009, 63 (Suppl. 2), S5-S21. [CrossRef] [PubMed]

100. Mozaffarian, D. Trans fatty acids-Effects on systemic inflammation and endothelial function. Atheroscler. Suppl. 2006, 7, 29-32. [CrossRef] [PubMed]

(C) 2018 by the author. Licensee MDPI, Basel, Switzerland. This article is an open access article distributed under the terms and conditions of the Creative Commons Attribution (CC BY) license (http://creativecommons.org/licenses/by/4.0/). 